\title{
THE RIGHT TO ACCESS BANKING DATA IN A CLAIM FOR A DIVISION OF COMBINED ASSETS THAT IS FILED SEPARATELY FROM A DIVORCE CLAIM
}

\author{
Faizal Kurniawan'; Xavier Nugraha²; Bagus Oktafian Abrianto; \\ Syifa Ramadhanti ${ }^{4}$ \\ 1,2,3,4Faculty of Law, Universitas Airlangga \\ Email: faizal@fh.unair.ac.id
}

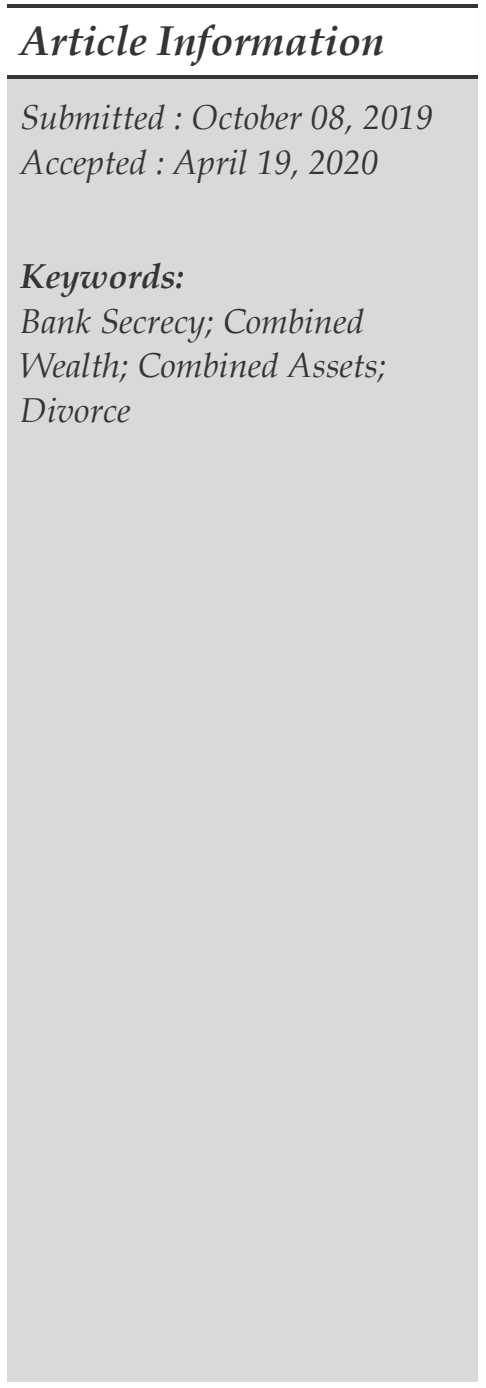

\begin{abstract}
Bank Secrecy remains one of the most essential principles of banking. In Indonesia, however, this principle is not absolute. According to Indonesia regulation, there are several exceptions in implementing Bank Secrecy. In its implementation, these exceptions have yet to adjust to recent social development. One problematic case is when it relates to a claim of combined assets that is filed in conjunction with a claim for divorce. In a recent development, the Constitutional Court has asserted that one of the exceptions for Bank Secrecy can occur for cases of divorce, in its Judgement Number 64/PUU-X/2012. However, this decision has yet to answer a problematic issue when the claim for divorct is filed separately from the claim for the division of combinea assets. Such a decision does not consider cases in which the two aforementioned claims are filed separately. This presents a problem for couples who are not Muslim and are confined to divorce laws in which the two claims must be filed separately. Thus, does a claim for the division of combined assets that are filed separately from the claim of divorce fall under the Scope of Constitutional Court Decision Number 64/PUU-X/2012? According to the following research, such cases indeed fall under the scope of Constitutionai Court Decision Number 64/PUU-X/2012. This conclusion is based on historical interpretation and Extensive Interpretation. According to historical interpretation, the original intent of the judges in drafting Constitutional Court Decision Number 64, PUU-X/2012 is to provide both the husband/wife equal share of their wealth. According to extensive interpretation, the concept of filing both claims separately is to an extension of the concept explicitly addressed in such a Constitutional Court decision.
\end{abstract}

\section{Introduction}

According to Article 1 (2) of Law Number 10 of 1998 regarding Changes to Law Number 7 of 1992 regarding Banking (hereinafter "Banking Act"), it is elaborated that a Bank is an institution that will manage the funds of the people in the form of loans and distribute those funds to the people in the form of credit and/or other forms, to increase the livelihood of the people. Based on the aforementioned article, it is evident that banks

46 Yustisia Volume 9 Number 1 (January-April 2020)

The Right to Access Banking Data...

(C)2020; This is an Open Access Research distributed under the term of the Creative Commons Attribution Licencee (https://Creativecommons.org/licences/by/4.0), which permits unrestricted use, distribution, and reproduction in any medium, provided the original works is properly cited. 
retain functions as an institution that will retain the funds of the people. Thus, the level of public trust is required (Kuswara, 2017).

A bank's existence as part of the monetary system and payment system creates a level of trust between the people and the institution which remains essential to a bank's existence. This trust originally exists in the exercise of a bank's fundamental functions which creates a relationship between the bank and the customer. If the customer does not trust the bank, they would surely not attempt to form any kind of working relationship with that bank. The starting point of this relationship is essential in establishing this trust between the bank and the customer.

Concerning the activities of the bank, there exist some fundamental obligations that a bank must conduct. According to scholar Ronny Sutma Hotma Bako, such fundamental obligations are as follows (Bako, 1995) :

1) A bank is obliged to maintain the funds of the customer as a secret;

2) A bank is obliged to secure the funds of its customers;

3) A bank is obliged to receive some amount of funds from its customers;

4) A bank is obliged to report its activities transparently to the people;

5) A bank is obliged to know its customers.

According to such fundamental obligations, it is evident that a bank must obtain a level of secrecy concerning its customers. This consequently creates the principle of Bank Secrecy that every Bank must execute in the exercise of its function as an agency of trust to the people in managing their funds (Muhammad Djumhana, 2000).

The existence of a ratio legis in maintain Bank Secrecy is as follows (Bako, 1995) :

1. The right of each individual or legal entity to remain not interfered with regards to personal issues. The existence of a legal relationship between the bank and the individual consequently provides the bank with the inherent obligation to protect the needs of its customers (Muchammad Arya Wijaya, 2017).

2. The rights that are present as a result of the legal relationship between a bank and a customer;

3. Based on the regulations outlined in The Banking Act Number 7 of the Year 1992 (now recognized as Law Number10 of the Year 1998), which asserts that based on the fundamental functions of the bank to obtain the funds of the people must operate based on trust from the people. Thus, a bank's knowledge of a customer's economic situation must not be abused and must be protected by each bank;

4. Customary and legitimate principles recognized by the Banking World;

5. Characteristics of Banking Activities.

Regarding the principle of bank secrecy that must be performed by each banking institution, according to Article 1 (28) of the Banking Act jo. Article 1 (6) of Bank Indonesia Regulation Number 2/19/PBI/2000 regarding the Requirements and Regulations to provide mandates or Written Permits to obtain Bank Secrets (hereinafter "PBI of Bank Secrecy"), it was elaborated that Bank Secrecy is everything that is concerning a customer's loaning activities and its loans. Thus, everything that is deemed correlating

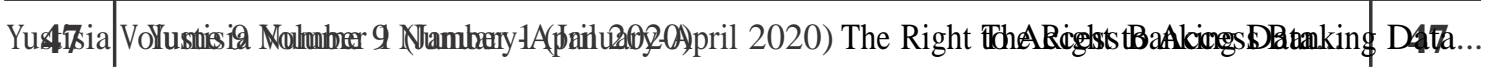


to a customer's banking activities and his/her funds is considered as Bank Secrets. Concerning the obligations of a Bank to retain Bank secrets, as regulated under Article 40 (1) of Banking Act. It is then re-asserted in Article 40 that a customer is a person who is either storing funds or borrowing funds from the banking institutions (According to the Explanation of Article 40). As a result, the fundamental understanding of Bank Secrecy is the prohibition of banking institutions in providing information or explanations to ay party regarding the economic situation of a customer and other information that must be kept a secret for the interest of that specific customer.

Aside from the Banking Act, there exist some regulations that also assert the importance of protecting a customer's details. Among those are Law Number 14 of 2008 regarding Public Information (hereinafter "Public Information Act"). In several provisions of the Public Information Act, the legislation bans the disclosure of information regarding banking activities, such as the changes in interest rates, loan rates, economic status, existing assets, etc. (Article 17 (e) and (f) of Law Number 14 of 2008 regarding Public Information). The principles of Bank Secrecy can also be found in the Ministry of Communication and Information Regulation Number 26 of 2016 regarding the protection of Personal Data in Electronic Systems (hereinafter "PERMEN KOMINFO regarding the Protection of Personal Data). Within such regulation, Bank Secrecy remains as one of the personal data that must be protected, following Article 1 (1). The protection of personal data invokes several things which are the protection for obtaining, collecting, managing, analyzing, storing, showcasing, announcing, sending, distributing, and extinguishing personal data (Article 2 of Law Number 14 of 2008 regarding Public Information). Thus, it can be concluded that personal data does fall under the scope of customer data obtained in Banks that must be protected, nurtured, and kept under secret.

Even though Bank Secrecy is one of the most important things in ensuring the trust between a bank and a customer, Indonesian Law does not see this principle as absolute. Bank Secrecy can be deterred in certain instances. These exceptions are regulated under Article 41, Article 41(A), Article 42, Article 43, Article 44, Article 44(A) of the Banking Act jo. Article 2(4) PBI on Bank Secrecy. For instance, in criminal law practices, when there exists a need to deter Bank Secrecy to obtain concrete evidence that will resolve criminal disputes, the Head of Bank Indonesia can issue a permit to the police, judge or judicial office to obtain a statement letter from the Bank regarding the accounts of the suspects (Article 42 of Law Number 14 of 2008 regarding Public Information). There also exist instances in which a request, permits, or authority from the customer was filed to a bank to obtain his/her information. In those instances, Bank Secrecy remains as not absolute in cases where it is necessary to deter such principles, under existing procedures outlined in banking regulations.

In its development, according to Constitutional Court Decision Number 64/ PUU-X/2012 Bank secrecy can also be deterred in cases of divorce, especially those relating to the division of combined wealth obtained individually or during the marriage. Within a marriage, both the wife and the husband have a right to utilize their obtained wealth, when the couple files for divorce this obstructs their legal relationship to utilize

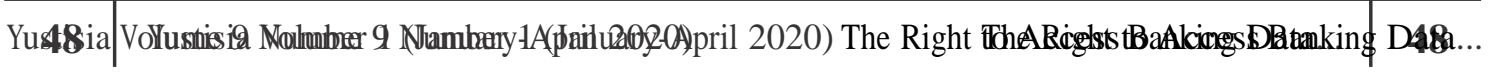


such wealth. In cases where one party feels the need to understand wealth that might not be made under his/her name, the principle of Bank Secrecy can be 
deterred. Under Constitutional Court Decision Number 64/PUU-X/2012 regarding testing for Law Number 10 of the Year 1998 regarding changes for Law Number 7 of the Year 1992 regarding banking, an applicant filing for a claim of divorce and division of wealth, in which such heath comes in the form of savings and deposits that is opened by another party, one of the parties might deny the existence of such assets within those accounts. Those, in those particular cases, Bank Secrecy must be deterred to resolve the dispute. The constitutional court decision states that Article 40 (1) of Law Number 10 of 1998 regarding changes on Law number 7 of 1992 regarding Banking which regulates that banking secrets must be protected by the Bank contradicts the spirit of the 1945 Indonesian Constitution and has no legally binding power when disclosure is required for judicial purposes regarding combined wealth in divorce cases (Page 30, points [3.16], Constitutional Court Decision number 64/PUU-X/2012), in this regard it can be said that Bank Secrets can be disclosed in cases involving the separation of combined wealth in divorce cases to reach an equitable solution. The constitutional court decision applies to bank secrets disclosed in cases whereby the claim for divorce is filed in conjunction with the claim for the separation of combined wealth.

Even when bank secrets can be disclosed in cases whereby a claim for divorce is filed in conjunction with the claim for separation of combined wealth, Article 86 (1) of Law Number 7 of the year 1989 that is then altered by Law Number 5 of 2009 regarding the Second Changes to Law Number 7 of 1989 (hereinafter 'Religion Court Act'), regulates that there exist 2 formats to file a claim for divorce in Indonesia. the first is when the claim for divorce if files in conjunction with the claim for the separation of combined wealth. This is also known as samenvoeging van vordering (cumulated claims), that is often practices in cases where divorce is a sign of the end of a contractual marriage. Under this understanding, marriage is seen as a form of legal relationship. When this legal relationship comes to an end, this results in a legal consequence which is the division of combined wealth obtained by the wife and husband during their marriage. This is in line with Article 35 of Law Number 16 of 2019 about amendment of Law Number 1 of the Year 1974 regarding marriage, in which the procedural aspect is regulated in Article 7 of 1989 regarding Religion (Nagara, 2016).

The second method of filing a divorce claim is filing the claim for divorce and the division of combined wealth separately. Under this method, a decision regarding the end of the couple's marital relationship needs to firstly be adjudicated before they can file for a claim of the division of combined wealth. In practice, there exists a much more substantial preference for the second method of filing a divorce claim rather than the first. Whereby a trial discussing the claim for divorce is conducted first before the couple chooses to file a claim on the issue of division of combined wealth (Hukumonline, 2018).

Aside from such methods, according to Neng Djubaedah, a lecturer at the Faculty of Law at UNS, non-muslim couples are not allowed to conduct combined trials for the claim for divorce and claim for division of wealth. This is due to the fact that they must abide by the regulations outlined in the Herziene Inlandsch Reglement (HIR). According to the HIR, the trials discussing the claim for divorce must be conducted first before the

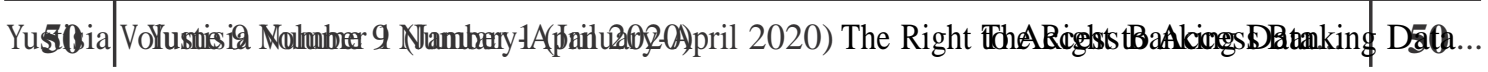


claim for the division of wealth in municipal courts (Hukumonline, 2018). This is also inline with the Decision of the Supreme Court Number 2205 K/Pdt/1981, where the 
practices codified in the HIR does not allow an applicant to combine a claim for divorce with a claim for the division of combined wealth (Apriyani Risna, 2016). This is reasoned by the fact that HIR recognizes the two claims as independent, with the claim for divorce being addressed first before the claim for the division of combined wealth. A claim for the division of combined wealth can only be decided upon the existence of a decision on a claim of divorce. Thus, the practice to combine the two claims is non-recognizable under the HIR.

Based on the aforementioned reasoning, it can be seen that the claim for divorce will almost always be filed separately from the claim for the division of combined wealth. Within such cases, can a claim for the division of combined wealth that is filed separately from the claim for divorce be an exception to the principle of Bank Secrecy? Is the exclusion for the principles of Bank Secrecy only applicable to a claim for the division of combined wealth that is filed in conjunction with the claim for divorce? What kind of claim for combined wealth can be an exception to the principle of Bank Secrecy, especially in cases for Muslim couples? This takes into account that non-muslim couples are not allowed to file a claim for the division of combined wealth in conjunction with the claim for divorce. So why does the claim for the division of combined wealth can become an exception to the principles of Bank Secrecy? And Can a claim for the division of combined wealth that is filed separately from the claim for divorce can be an exception to the principles of Bank Secrecy?

\section{Research Methods}

This paper is a legal argumentation research paper that focuses on its main aspects of the decision of several cases, complemented by legal argumentations/considerations that are drafted by legal practitioners. Alongside such an application, this research will look at the interpretation in those decisions (Nugraha, Izzaty, \& Putri, 2019). This research is conducted with normative research. Normative research is a method of study that places law as a fundamental part of building a system of norms that is constructed by principles, norms, and practices from legislations, judicial decisions and doctrines (Depri Liber Sonata, 2017). This formative research will be conducted by drafting and analyzing legislation and other legal products that are concerning the issue of Bank Secrecy in claims for divorce and division of combined wealth.

This research utilizes approaches to existing legislations also known as statute approach, conceptual approach, and case approach.

Statute approach is conducted by examining all existing regulations and laws that discuss the related legal issue that is addressed, this provides a broader understanding of existing rules governing bank secrecy and claims for divorce alongside claims for the division of combined wealth. The statute approach will be utilized in this research as a normative research paper that analyses several (Ibrahim, 2017). Among those regulations are Law Number 10 of 1998 regarding changes to Law Number 7 of 1992 regarding Banking, Law Number 14 of 2008 regarding public information, Ministry of Communications and Information Technology Regulation Number 20 of 2016 regarding the Protection of Electronic Systems Data and many others. Based on the aforementioned

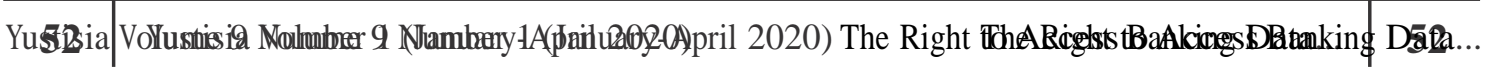


regulations, Ronald Dworkin asserts that such research can also be classified as doctrinal research, which is research that analyses the law, including those written in books (law as it is written in the book) (Thaufik Amirullah, Nurjaya, \& Bambang Sugiri, 2014).

A conceptual approach is an approach that stems from several views and doctrines that have evolved in the field of law (Barus, 2017). This approach is conducted with an understanding of the concept of bank secrecy in claims for divorce alongside claims for the division of combined wealth.

The case approach utilizes judicial decisions as a source of law. Judicial decisions that are utilized are judge's decisions that have a legally binding power (Oly Vina Agustine, 2018). When discussing judicial decisions as a source of primary law, it can be said that the legally binding power of that judgment lies in its ratio decidendi, which is the legal reasoning that is utilized by the judge in determining its decision (judge consideration) that is elaborated in Constitutional Court Decision, Number 64/PUU-X/2012, regarding the disclosure of bank secrets in claims for divorce and claims for dividing combined wealth.

The technical analysis conducted in this research was conducted through prescriptive analytics that aims to produce prescriptions regarding what should be the essence of this legal research that fundamentally holds on to the characteristics of law as a field of study. The result of this analysis will be formed utilizing legal logic, legal argumentation, and legal principles that will create a conclusion as an answer to the problem statement of this research paper (Marzuki, 2010).

\section{Research Result and Discussion}

A. A claim for the division of combines wealth that is filed in conjunction with a claim for divorce as an exception for the disclosure of Bank Secrets

Bank secrets are one form of legal protection, existing regulations that govern the application of bank secrets discusses everything that is in relation with monetary practices to the customer's personal information, under the principle of legality and banking obligations. "In regards to this relationship, what is meant by bank secrets in every kind of data and information regarding a person and an institution that falls under the rightful knowledge of the bank in fulfilling the bank's main obligations. Bank secrets should be places at an important position, recognizing the amount of wealth stored in banks by individuals that have the right to be kept secret from the general public (Mohammad Rizaldi Syamsu, 2013).

There exist 2 theories that highlight the characteristics of bank secrets, where first and foremost, bank secrets are absolute and second that bank secrets are measurable. Existing theories that argue that bank secrets are absolute means that banks are obliged to keep their customer's information secret in ordinary or extraordinary circumstances. The second theory states that bank secrets are measurable which means that banks can disclose their secrets in urgent cases, for

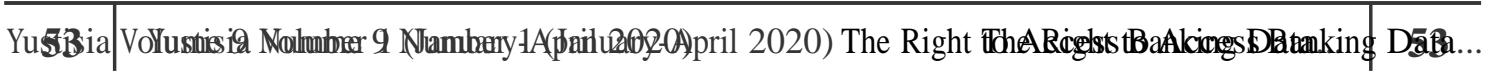


instance in cases of state emergency. In certain cases and force certain parties, bank secrets can be disclosed. Even in cases of disclosing a person's financial 
situation, banks are not the only authorized party to do so, disclosing this kind of information is often deemed necessary and not done in violation of the bank secrecy principle (Pramoto, 2011).

It can be seen that in Indonesia, in regards to Bank secrecy, it is a principle that every individual has the right of protection following Article 28(G) of the 1945 Indonesian Constitution (hereinafter the "1945 Constitution"). However, Bank secrets can also be categorized as derogable rights. The fact that bank secrets are derogable rights does not mean that these rights are limited. There exists 2 cumulative requirements for a state to limit derogable rights. These 2 cumulative rights must be following Article 38 J 92) of the 1945 Constitution as asserted in the Constitutional Court Decision Number 2-3/PUU-V/2007, as such (Hastuti, 2016):

1. Limiting such rights under existing regulations

2. Limitations are conducted to ensure recognition and honor over the rights and freedom of others to fulfill a just judgment under moral considerations, religious principles, security and public order in a democratic society

Thus, it can be seen, that even when the principles of bank secrecy is a human right that is ensured in Article $28 \mathrm{G}$ of the 1945 Constitution, this type of human right can be limited in which those limitations are regulated under Article 40 of the Banking Act and the reasoning behind such limitations is to fulfill the rights of other or for the sake of public order (taxation obligations, finishing banking debs that have been given to the Body for Credit Matters and State Action/ Committee for management of State Debt, judicial needs in criminal cases and other affairs that is considered as general needs or for the sake of protecting another person's rights). With the existence of such exceptions to banking rights, it can be concluded that Indonesia adopts the measurable theory.

By the adoption of the measurable theory, by principle, each customer's data must be protected by the bank. However, certain conditions verified under the Banking Act and PBI of Bank Secrecy provide certain exceptions in which customer data can be accessed for certain affairs. For example, in cases of taxation cases (Article 41 of the Banking Act), finishing issues of bank debts that have been handed over to the Body for Debt affairs and State Auction (Article

$41 \mathrm{~A}$ of the Banking Act), criminal cases (Article 42 of the Banking Act), civil cases between a bank and its customers (Article 44), under the agreement or authority of the customer in written form (Article 44A of the Banking Act) and under the request of an heir from a customer that has been deceased (Article 2 (4) letter $g$ of the PBI on Bank Secrecy) (Hukumonline, 2018).

Het Recht Hink Achter De Feiten Aan, a postulate that presented a meaning that laws will always be behind of current events. A postulate that is quite a satire to current legal conditions in which it considers that it will always be behind, stating that before there exists a law that regulates such actions, the actions will always occur first (Nugraha, Rahardjo, et al., 2019). Even within Banking Act and PBI on Bank Secrecy, it regulates several instances in which bank secrets

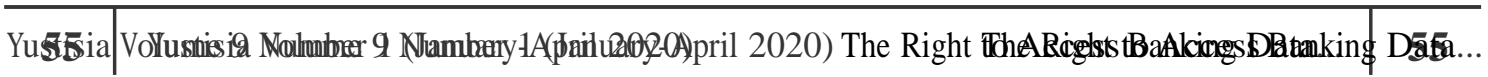


can be disclosed, however in its development, there exist several cases that do indeed provide an exception to bank secrecy. Such instances include the claim for the division of combined wealth in a divorce case.

Under Article 39 (1) of the Marriage Act, it is elaborated that "Divorce can only be done through a trial after the court has tried and failed to maintain the peace between the parties." A divorce brings forth a legal consequence which cuts-off the marital relationship between a wife and a husband, it also stops a family relationship and a combined wealth relationship. A family relationship and a relationship established by combined wealth are closely intertwined, although the two relationships are distinguishable, they cannot be separated. A legal relationship based on family determined the inheritance wealth and the combined wealth of the individuals involved (Wijayanti Winda, 2013). Thus, the end of marriage presents a juridical consequence that results at the end of a legal relationship concerning a wife/husband's wealth that is once combined.

The division of marital wealth must be followed by a division of combined wealth that is just between both parties. The meaning of just in this instance is to divide the combined wealth equitably in accordance with Article 128 of the Civil Code (Hereinafter "KUHPer") jo. Article 97 of the Compilation of Islamic Law that is valid based on Presidential Instruction (Inpres) Number 1 of the Year 1991 (hereinafter "KHI"). A parties' share to combined wealth must be decided in accordance with the theory of Justice as Fairness that was introduced by John Rawls in his book "A Theory of Justice", in which just means that every person must retain the same rights over fundamental freedoms, this freedom must be retained by everyone (John Rawls, 2009). This means that a wife and a husband, as equal human beings, retain the same rights and deserved the same amount of shares for their combined wealth.

In order to divide combined wealth equitable between the husband and the wife, there needs to exist adequate information regarding riil wealth between the parties. If there exists no clear disclosure regarding the existing riil wealth, there would be no possible way to divide such wealth equitable. Thus, in order to understand fully the amount of wealth that both parties have, the couple needs to have access to bank secrets as the wealth in stored within banks. This includes the protection of the rights of the wife and husband over their combined wealth that is held within banks, in the form of savings accounts, deposits and other types of banking products. These rights must also be protected equally between the wife and the husband as they both can be hiding wealth within such banking products. The protection of these rights are substantially regulated under Article 35 jo. 36 jis. 37 of the Banking Act.

In discussing access to bank secrets in claims for division of combined wealth in divorce cases, both the wife and husband would plead to the Constitutional Court to become an asbahun nuzul, in order to retain their rights substantially. Such request first began by Magda who filed the request because she was not

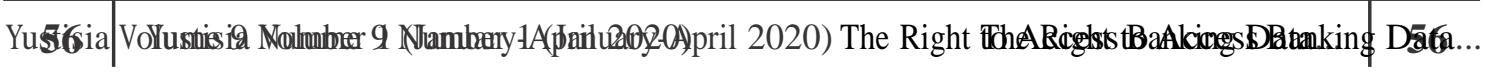


allowed by the bank to access their family's combined wealth data in some accounts under her husband's name. Thus, this was filed as her divorce case

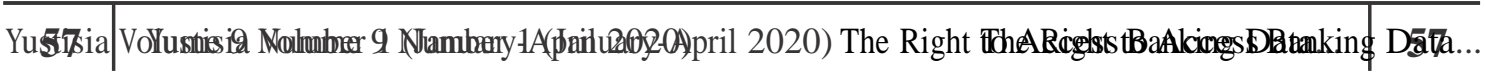


was ongoing in the Syariah Court of Banda Aceh. When such court requested clarifications to the affiliated banks, such institutions rejected the request under Article 49 (1) and (2) of the Banking Act jo. Article 2 of PBI on Bank Secrecy which does not recognize exceptions to the principle of bank secrecy in regards to claims of combined wealth in divorce cases (Dwiyatmi \& Wauran, 2017).

With the non-existence of exceptions to the principle of bank secrecy regarding claims of combined wealth in divorce cases, this can substantially injure the rights of the wife/husband, in accordance with Article 35 jo. 36 jis. 37 Banking Act. Whereby in those Articles, it was elaborated that:

Article 35 (1)

Wealth that is obtained during the course of the marriage is considered as combined wealth/marital wealth

Article 36 (1)

In regards to combined wealth, the husband or wife can act based on the agreement of both parties

Article 37

In the case of divorce, combined wealth will be regulated under existing regulations

Further, Article 1 letter $\mathrm{f}$ of the Compilation of Islamic Law that is valid based on Presidential Instruction (Inpres) Number 1 of 1991 (hereinafter "KHI") states that, "Wealth in a marriage (combined wealth/marital wealth) is wealth brought by the individual or obtained during the marriage, without issues of registration under a specific name." Based on such explanations, there exist several criteria for what is considered as combined wealth. Such criteria are:

1. Combined wealth is wealth in a marriage, which is wealth obtained individually or together;

2. Obtained during the marriage

3. Without issues of registration under a specific name.

As long as those 3 (three) requirements are fulfilled, then the standing of an asset or an object obtained by the wife or husband during the course of their marriage is, by law and under existing regulations, considered as combined wealth, without considering whether or not such item is registered or registered under who's a name.

Referring to Marriage Law, especially Article 35 (1), Article 37, as well as Presidential Instruction Number 1 of 1991 regarding the Compilation on Islamic Law, especially Article 1 letter $\mathrm{f}$ regarding savings, deposits and wealth as well as other banking products that are utilized by the husband or the wife, such wealth, is recognized as combined wealth. Thus, combined wealth obtained during the course of marriage, including wealth kept by the husband and/or wife in one bank in the form of a savings account, deposits, and other banking

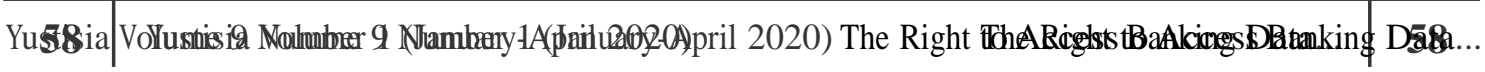


products are considered as combined wealth jointly owned by the husband/ wife.

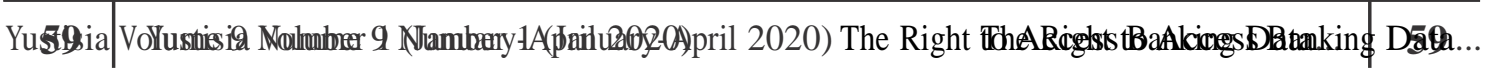


Additionally, the empirical dispute in the division of combined wealth in divorce cases is an event that often happens in the general public. Such event often results in material loss for one disputing party, such losses has or will happen because of bank secrecy as regulated in Article 40(1) and (2) of the Banking Act. A legal tool that provides a literia legis interpretation, which is a literal interpretation, that analyses the legislation word-by-word without looking at the spirit of such provisions, in Article 40 (1) and (2) of Banking Law jo. Article 2 PBI on Bank Secrecy, without looking at the sintetia legis (interpretation not explicitly bound to a word, phrase or sentence within a legislation. Further interpretation must comprehend what the true meaning or 'spirit' of a regulation in existing legislations regarding Bank Secrecy. In reality, to understand the 'spirit' of the exception of Bank Secrecy is to provide protection on the the bigger interest and objectives of others, in accordance with principles introduced by Jeremy Bentham, which is the greatest happiness for the greatest happiness (Lorenzo Cello, 2020).

Thus, legal practitioners must attempt to interpret the law not only through a literia legis approach, limited to Article 40 (1) of Banking Law and PBI on Bank Secrecy, but also attempt to interpret the law through a sintetia legis approach to protect the common interest, namely to protect the rights of the husband/wife. This is in accordance with the opinions of Gustav Radbruch, who believes that the law is normative because it must reflect justice and utility which in turn does not require the assertion of its normative characteristic when it no longer reflects such values (Lorenzo Cello, 2020). Thus, legal practitioners must not only look at the limitations to existing normative regulations but also look that there exist exceptions for bank secrets for combined claims. To provide justice to the husband/wife that will obtain a share of their combined wealth in accordance with the principles of justice and its future uses.

Because there exist financial accounts of a husband/wife that is held under different parties, it cannot be said that these circumstances can be categorizes as 'in-line with the needs of the people'. This is because the legal substance has yet to follow the progress and legal practitioners have yet to utilize sintetia legis interpretation. The Constitutional Court, through decision Number 64/ PUU-X/2012, provided an interpretation/clarification on the issue of bank secrecy that is exempted in Article 40 (1) and (2) of Banking Act as a step towards progressive law. (Constitutional Court Decision, Number 64/PUU-X/2012, P.7).

The Constitutional Court, through decision Number 64/PUU-X/2012 views that justice will be fulfilled if a customer's data shall be disclosed in civil cases regard combined wealth, because combined wealth is shared between husband and wife. Due to such, both the wife and/or the husband must obtain protection over their rights and these rights cannot be arbitrarily taken by one party. This is also ensured in Article 28G 91) and Article 28H (4) of the 1945 Constitution. ( Considerations of the Constitutional Court [2/14] in Constitutional Court 
Decision, Number 64/PUU-X/2012, p. 29). Thus, the Constitutional Court then provides an interpretation to Article 40 of the Banking Act in an effort to 
create legal substance and legal practice that is progressive to existing social changes, codified in "Article 40 (1) of Law Number 10 of 1998 regarding changes on Law Number 7 of 1992 regarding Banking (Republic of Indonesia Files on 1998 Number 182, Additional Files of the Republic of Indonesia Number 3790) does not have a legally binding power as long as it is not applies in matters dealing with court claims of division of combined wealth in divorce cases (Constitutional Court Decision, Number 64/PUU-X/2012, P. 32). Thus, the results of this Constitutional Court Decision, Number 64/PUU-X/2012, provides an obligation for the bank to disclose information in cases of division of combined wealth.

B. A claim for the division of combines wealth that is filed separately from a claim for divorce as an exception for the disclosure of Bank Secrets

In principle, each claim must stand on their own. Each claim must be filed in a separate application to the court that is independent from one another and such claims shall be addressed as well as adjudicated that is separate from one another. In certain cases, however, claims can be combined in one application when both claims retain a close relationship or connectivity. (Supreme Court, 1994: p. 125). One of the forms to combine applications can be seen in a claim for the division of combined wealth that is filed together with a claim for divorce in Religion Court. This can be seen in Article 86 (1) of Law on Religion Court, which states:

(1) Applications regarding child custody, child care, alimony and combined wealth between a husband and wife can be filed together with the claim for divorce or after the decision on the divorce has been rendered as having legallybinding powers.

This showcases that in Islamic Law, because there exists a strong connectivity between the claim for divorce and the claim for the division of combined wealth, there also exists a possibility of combining their applications. This is also known as samenvoeging van voerdering or cumulated claims.

In Religion Court, there exists practices where claims for divorce is accumulated with the claim for the division of combined wealth, considering them as an accesoir claim to the issue of divorce. The way in which an accesoir is asserted is if the claim for divorce is automatically rejected which results in the rejection of the claim for the division of combined wealth (also known as nietont vankelijk verklaard). Likewise, if the claim for divorce is approved than the division of combined wealth will also be approved for adjudication (Helmi, 2014).

When looking at this issue theoretically from a judicial standpoint, filing a claim between divorce and the claim regarding combined wealth cumulatively is the most effective and efficient way that will bring forth the most benefit as it would not waste time in Religion Court. This is because the applicant can

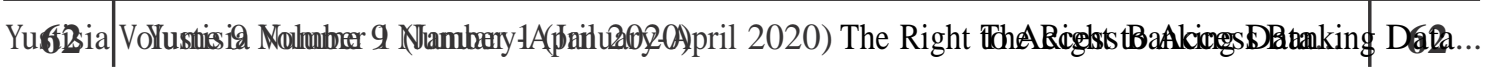


file two claims at the same time, which are the claim for divorce and the claim for the division of combined wealth. Although both claims have different 
characteristics, whereby the claim for divorce is the primary claim whilst the claim for the division of combined wealth is an accessoir claim that attaches itself to the primary claim. The combination of these two claims in the actualization of the principles of the court to be swift, simple and affordable (Astriani Van Bone, 2017).

Even when there exists a possibility for a cumulative claim to be files to the court in regards to the claim for divorce and the claim for the division of combined wealth, a cumulative claim is the fulfillment of the principles of the court to be swift, simple and affordable. However, this application does not hinder the possibility that such claims can be separated. This is because, in accordance to Article 86 (1), the word "may" was used. As a consequence, there exists room for a cumulative claim to be separated. In practice, the issue of the division of combined wealth is usually adjudicated after the existence of a legally-binding decision (inkracht van gewijsde).

Different from the practices of Religion Court where cumulative claims are recognized, in other cases, municipal courts usually recognize two separate claims for the issue of divorce and the division of combined wealth. The municipal court, in adjudicating matter of divorce in accordance with civil procedural law, adjudicates first the issue of divorce until it reaches a legally-binding decision. After the existence of such legally-binding decision, only then can the claim for the division of combined wealth be adjudicated by the Court. This showcases that couple who are not muslim or couples who must abide to existing national civil procedure cannot present a cumulative claim for the issue of divorce and the issue of division of combined wealth.

From the jurisprudence of the Supreme Court Number $2205 \mathrm{~K} / \mathrm{Pdt} / 1981$ dated 30 June 1984 which states that, "A cumulative claim on the issue of divorce and division of combined wealth cannot be justified (Pranoto, P., Kholil, M., \& Tejomurti, K. 2019: 105) . Based on such a decision, civil procedural law does not allow the combination of such claims. This is also canon to the Jurisprudence of the Supreme Court Number 913 K/Sip/1982, dated 21 Mei 1983 which states that "Claim regarding divorce cannot be filed in conjunction with the claims for the division of combined wealth". This is also written in the Jurisprudence of the Supreme Court Number: 1020 K/Pdt/1986, dated 29 September 1987, which states, "... the claim for the division of combined wealth cannot be filed together with the claim for divorce". With the existence of 3 jurisprudence with regards to this issue, it can be said that there exists fasten jurisprudence or absolute jurisprudence regarding the prohibition of the combination of the two claims.

Citations non-concedantur priusquam exprimatur super qua re fieri debet citation, is a legal postulate saying which means that jurisprudence will not be accepted before there exists adequate argumentation behind it. Under this principle, the aforementioned judicial decisions can only be used as legal argumentation, by examining the ratio decedendi behind such jurisprudences. In this regard, the ratio

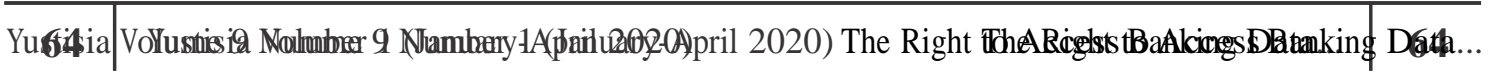


decidendi form the 3 jurisprudences regarding the prohibition of filing a cumulative claim on the issue of divorce and division of combined wealth in 
municipal courts. This is because the claim for divorce is placed in the beginning as a primary claim, whilst the division on combined wealth is placed after that. The claim for the division of combined wealth can only occur when there exists a judicial decision that is legally binding (in kracht van gewisjde) regarding the issue of divorce.

Based on such an explanation, there exist several conditions for the separation of filing both claims. Which are:

1. For couples who are muslim, they can file a claim for the division of combined wealth after filing the claim for divorce

2. For couples who are not muslim and must abide by existing civil procedural law, they must follow national legislation

In cases whereby the claim for the division of combined wealth is filed separately from the claim for divorce or in other words after the existence of a legally-binding decision on the issue of divorce, this presents a problem to the exceptions on bank secrecy as regulated in Constitutional Court Decision, Number 64/PUU-X/2012. This is because such a Constitutional Court decision only regulates issues of the division of wealth that is filed in conjunction with the issue of the division of combined wealth.

To determine whether or not non-cumulative claims can be an exception to the principles of banks secrecy, much like a cumulative claim on divorce and combined wealth can fall under such exceptions, an interpretation is required. Legal interpretations is an approach on a legal discovery that has been rendered but is rather ambiguous in practice. Likewise, interpretation can also be used to adjudicate and examine issues that have yet to be regulates (Afif Kahlid, 2014). According to Sidharta, there exists 9 types of legal interpretation, which are (Sidharta, 2013):

a) Grammatical (Objective)

Interpretation according to language, looking at its lexical definition.

An example: "Embezzling Items" (Article 41 of the Criminal Code hereinafter "KUHP") is defined as "losing or stealing an item that is trusted upon an individual."

b) Authentic

Interpretation based on the limitations of existing regulations that is usually outlined in the explanation (memorie van toeclichting), the formula for its general regulations, as well as its other provisions.

Example: All terms of "investigator" written in the Criminal Procedural Code (Hereinafter "KUHAP"), which includes senators of the Republic of Indonesia or other civil servants that is provided special authority by the law to conduct an investigation

c) Theological (Sociology)

Interpretation based on humanitarian purposes

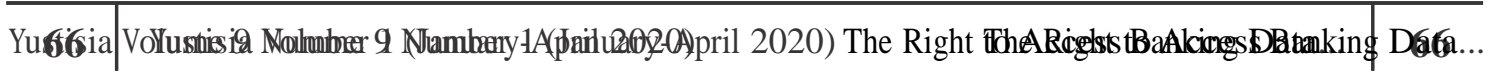


Example: Article 534 of the KUHP regarding the prohibition on abortion

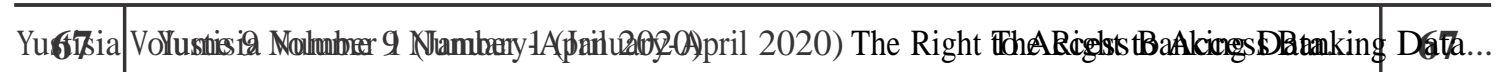


that is criminalized for sociological purposes (in accordance with Planned Parenthood programs)

d) Systematic (Logic)

Interpretation that connects one rule with another.

Example: regulations regarding the acknowledgement of an offspring KUHPer interpreted in accordance with Article 278 KUHP

e) Historical (Subjective)

Interpretation that examines the historical background or history of a certain regulations (history of the legislative).

Example: The word 'Indonesia' in Article 6 of the 1945 Constitution (before its III Revision) is interpreted in accordance with the ideas in the BPUPKI and PPKI discussion of 1945

f) Comparative

Interpretation by comparing existing regulations in one legal system with another legal system.

Example: requirements of 'class action' in Article 46 of the Law on Consumer Protection interpreted by comparing the regulation with the requirements for class action of Article 23 of the US Federal Rule of Civil Procedure

g) Futuristic (anticipative)

Interpretation that relies on the formulation of legislations (ius constituendum). Example: The formulation of regulations on theft of electronical information through the internet that is based on the Bill on information Technology (that has yet to become formally recognized as a source of law).

h) Restrictive

Interpretation that provides limitations for regulations. Example: The term 'neighbour' in Article 666 of KUHPer must be the owner of the house next door

i) Extensive

Interpretation that broadens the scope of a regulation. Example: The term "neighbor" in Article 666 KUHPer does not necessarily mean the owner but merely a person that lives in the house next door.

Based on the 9 methods of interpretation, there exists 2 methods of interpretation that is relevant to the claim of divorce that is filed separately from the claim of the division of wealth as an exception for the principle of bank secrecy. Two methods of interpretation is the historical approach and the extensive interpretation.

\section{a) Historical Interpretation}

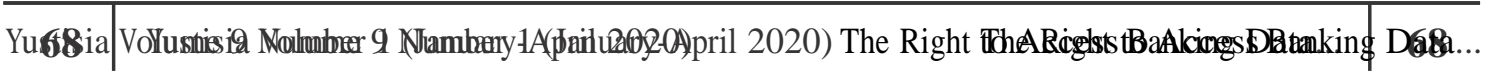


Scire leges non hoc est, verba earum tenere, sed vim ac potestatem, even though the regulation is clear, to fully interpret the legislation must consider the reasoning behind the formulation of such regulation. This

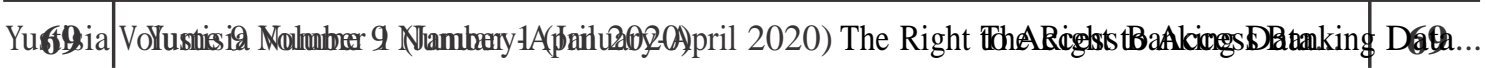


examines the meaning of such regulations and that the interpretation of the legislation must examine its original intent. Where it is contextualize in accordance with the application of the principle of bank secrecy, examining the historical context of Constitution Court Decision in interpreting Article 40 (1) of Banking Law, must consider such Constitutional Court decision.

In its reasoning, the Court held that the rights of the applicant in obtaining protection for his/her rights in accordance with Article 28 G (1) of the 1945 Constitution, whether it be a personal asset or combined wealth that is held within a bank under a spouse' name. The applicant still has the right to obtain such wealth. When examining the intent of the Constitutional Court that interprets the will of the legislators in creating Article 28 G (1) of the 1945 Constitution that states "protection, progression, enforcement and fulfillment of human rights is the obligation of the State" (Mahkamah Konstitusi, 2010), thus the changes to Article 40 (1) by the Constitutional Court airms to fulfill the inherent rights of the public substantially.

Additionally, when looking at the explanation of the court in that decision, the court interpreted Article 40 91) of Law Number 10/1998 in order to provide legal certainty and justice so that both the husband/ wife can obtain guarantee and legal certainty on their rights regarding to wealth that is stored in the bank. It can be seen that the original intent of the Constitutional Court decision Number 64/PUU-X/2012 is to provide husband/wife can gain an equitable portion of their wealth that is stored in banks, even when the claims are filed cumulatively or non-cumulatively. Historically, this is justified as it is the original intent of the constitutional court decision Number 64/puu-x/ 2012.

\section{b) Extensive Interpretation}

According to Sidharta, extensive interpretation is an interpretation that pushes forward the development of law. This is caused by the fact that through extensive interpretation there exists interpretation that is adjusted to the legal needs of society. Whereas lexical approaches often do not accommodate the needs of time (Sidharta, 2013).

In regards claims relating to the division of combined wealth that is filed separately from the claim of divorce, and whether or not they can be an exception to the principle of bank secrecy. When examining the constitutional court decision Number 64/PUU-X/2012 that has excluded the claim for the division of combined wealth that is filed in conjunction with the claim for divorce for issues concerning bank secrecy, by nature such interpretation can be seen in a broader sense. This is because, materially, both claims are materially similar. These differences only exists in the tempus of the application, which is either together or separate from the claim for

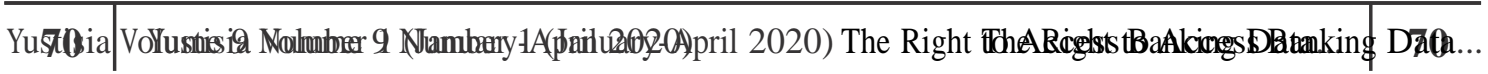


divorce. Because the only difference is on the issue of tempus, then it can be interpreted extensively.

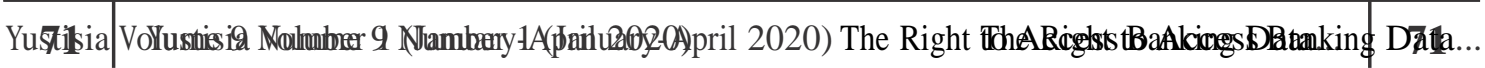




\section{Conclusion}

Based on the aforementioned elaboration, it can be concluded that a bank is an institution that provides trust to the people and thus must uphold the principles of bank secrecy. However, there exists some exceptions that are regulated within Article 40 of the Banking Act in which those secrets can be accessed. In it development, through the constitutional court decision Number 64/PUU-X/2012 has indeed provided an interpretation, that bank secrecy as regulated in Article 40 (1) of the Banking Law can be exempted for issues regarding the division of combined wealth that is filed in conjunction with the claim of divorce.

In cases where the claim for the division of combined wealth is filed separately from the claim of divorce, there must exists the exemption to the principles of bank secrecy, according to such regulated in constitutional court decision Number 64/PUU-X/2012. This is based on the historical and extensive interpretation towards those discussed in constitutional court decision Number 64/PUU-X/2012. Under historical interpretation, the original intent of the judges for that decision was examined in drafting constitutional court decision Number 64/PUU-X/2012, which is to ensure the equitable division of wealth between the husband/wife. Under the extensive interpretation, the concept of the claim for the division of combined wealth that is filed separately from the claim for divorce can also be exempted from the principle of bank secrecy because such interpretation allows the exclusion of such principles.

In an attempt to provide legal certainty to all of the parties involved in claims of division of wealth as an exemption for the principle of bank secrecy, this exemption should be included in the new bill for Banking act. This will create legal certainty for all stakeholders such as banks, wife/husband that are disputing, recollecting that a legislation is a legal product that has a legally-binding power in Indonesia. Thus, there exists no excuse for a bank to not provide bank secrets in issues of division of combines wealth, whether they are filed in conjunction or separately from the claim of divorce.

\section{BIBLIOGRAPHY:}

\section{Legal Documents:}

The 1945 Indonesian Constitution

Civil Code

Herziene Inlandsch Reglement

Law Number. 10 of 1998 On The Amendment of Law Number 7 of 1992 regarding Banking

Law Number 14 of 2008 regarding Public Information

Law Number 5 of 2009 regarding the Second Amendment to Law Number7 of 1989

Law Number 16 of 2019 On The Amendment of Law Number 1 of 1974 regarding marriage

Ministry of Communication and Information Regulation Number 26 of 2016 regarding the protection of Personal Data in Electronic Systems

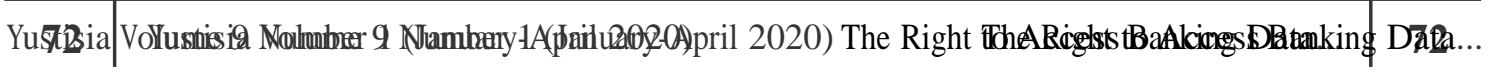


Bank Indonesia Regulation Number 2/19/PBI/2000 regarding the Requirements and Regulations to provide mandates or Written Permits to obtain Bank Secrets

Constitutional Court Decision Number 2-3/PUU-V/2007

Constitutional Court Decision Number 64/PUU-X/2012

\section{Books with an author:}

Bako, R. S. H. (1995). Hubungan Bank Dan Nasabah Terhadap Produk Tabungan Dan Deposito (Suatu Tinjauan Hukum Terhadap Perlindungan Deposan Di Indonesia Dewasa Ini. Jakarta: Citra Aditya Bakti.

Djumhana, Muhammad. (2000). Hukum Perbankan di Indonesia. Bandung: PT Citra Aditya Bakti.

Ibrahim, J. E. dan J. (2017). Metode Penelitian Hukum (Normatif dan Empiris). Jakarta: Pranada Media.

Mahkamah Konstitusi. (2010). Naskah Komprehensif Undang-Undang Dasar Negara Republik Indonesia Buku VIII. Jakarta: Sekretariat Jendral dan Kepaniteraan Mahkamah Konstitusi.

Marzuki, P. M. (2010). Penelitian Hukum. Jakarta: Prenada Media Group.

Nugraha, X., Rahardjo, A. P., Katherina, A. M. F., Tanbun, E. P., Aldi, J. A., Agustin, W., \& Cindy Cendhani. (2019). Iuris Muda: Bunga Rampai Ilmu Hukum. Yogyakarta: Harfeey.

Rawls, John. (2009). A Theory of Justice (Revised Ed). Cambridge: The Belknap Press of Harvard University Press.

Sidharta. (2013). Hukum Penalaran dan Penalaran Hukum (Akar Filosofis, Buku 1). Bandung: Genta Publishing.

\section{Journals:}

Agustine ,Oly Vina. (2018). Jurisprudence Enforceability on Judicial Review Authority in the Constitutional Court Decision. Jurnal Konstitusi, 15(3), 643.

Barus, Z. (2017). Analisis Filosofis Tentang Peta Konseptual Penelitian Hukum Normatif Dan Penelitian Hukum Sosiologis. Dinamika Hukum, 13(2), 313.

Bone ,Astriani Van. (2017). Penyelesaian Sengketa Harta Bersama Berstatus Agunan dalam Perkara Perceraian di Pengadilan Negeri. Lex Administratum, 5(5), 87.

Cello, Lorenzo. (2020). Jeremy Bentham's vision of international order. Cambridge Review of International Affairs, 33(1), 54.

Dwiyatmi, S. H., \& Wauran, I. (2017). Menembus Rahasia Bank Terkait Harta Bersama Dalam Perkawinan. Refleksi Hukum, 2(1), 100-101.

Hastuti, P. (2016). Studi Kritis Pasal 51 Ayat (1) UU Nomor 24 Tahun 2003 Juncto UU Nomor 8 Tahun 2011 tentang Mahkamah Konstitusi terhadap Perlindungan Hak Warga Negara Asing di Indonesia. Supermasi Hukum, 5(2), 202-203.

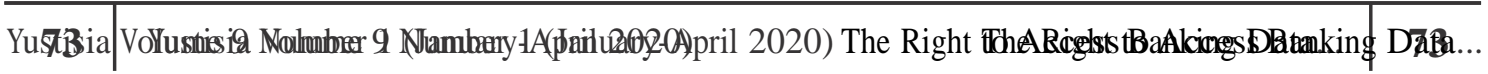


Helmi, M. (2014). Penerapan Asas Persidangan Gugatan Rekonvensi Perkara Perceraian dengan Harta Bersama. Ittihad, 12(21).

Kahlid, Afif. (2014). Penafsiran Hukum oleh Hakim dalam Sistem Peradilan di Indonesia. $A l^{\prime} \mathrm{Adl}, 6(11), 10$.

Kuswara, U. A. (2017). Analisis Terhadap Pelaksanaan Kerahasiaan Bank Berdasarkan UU Number 7 Tahun 1992 tentang Perbankan Sebagaimana Telah Diubah dengan UU Number 10 Tahun 1998 Pada PT. Bank Pembangunan Daerah Kalimantan Barat. Jurnal Nestor Magister Hukum, 2(2), 4-5.

Nagara, B. (2016). Pembagian Harta Gono-Gini Atau Harta Bersama Setelah Perceraian Menurut Undang-Undang Nomor 1 Tahun 1974. Lex Crimen, 5(7), 52.

Nugraha, X., Izzaty, R., \& Putri, A. A. (2019). Rekonstruksi Batas Usia Minimal Perkawinan Sebagai Bentuk Perlindungan Hukum. Lex Scientia, 3(1), 40-54.

Pranoto, P., Kholil, M., \& Tejomurti, K. (2019). FINTECH LENDING: CHALLENGE AND OPPORTUNITIES OF THE INDONESIA'S LOAN UNBANKED TO DEVELOP THE INCLUSIVE FINANCIAL INDUSTRY. Hang Tuah Law Journal, 3(2), 105-119.

Thaufik Amirullah, Nurjaya, I. N., \& Bambang Sugiri. (2014). Pertimbangan Hukum Hakim dalam Memutus Perkara Pembunuhan Berencana dengan Motif Persembahan Upacara Adat oleh Suku Noaulu Maluku Tengah (Studi Terhadap Putusan Nomor 87/Pid.B/2005/PN.Msh dan Putusan Nomor 25/Pid/2006/PT. Mal). Jurnal Hukum, 3(1), 6-7.

Sonata ,Depri Liber. (2017). Metode Penelitian Hukum Normatif dan Empiris: Karakteristik Khas dari Metode Meneliti Hukum. Fiat Justitia Jurnal Ilmu Hukum, 8(1), 25.

Syamsu ,Mohammad Rizaldi. (2013). Aspek Hukum Bank di Indonesia. Lex Privatum, $1(1), 28$.

Winda, Wijayanti. (2013). Kedudukan Istri dalam Pembagian Harta Bersama Akibat Putusnya Perkawinan Karena Perceraian Terkait Kerahasiaan Bank. Jurnal Konstitusi, 10(4), 6.

\section{Thesis:}

Pramoto, B. (2011). Analisis Yuridis Terhadap Pembukaan Rahasia Bank Berdasarkan UndangUndang Number8 Tahun 2010 Tentang Pencegahan dan Pemberantasan Tindak Pidana Pencucian Uang. Universitas Indonesia.

Risna, Apriyani. (2016). Analisis Yuridis Putusan Hakim Mengenai Penggabungan Perkara Perceraian Dan Harta Benda yang Diperoleh Selama Perkawinan (Studi Kasus Putusan MA Number656K/PDT/2012). Universitas Bhayangkara.

Wijaya ,Muchammad Arya. (2017). Pengungkapan Data Nasabah yang Dilakukan oleh Pers Ditinjau dari Prinsip Kerahasiaan Bank. Universitas Atmajaya.

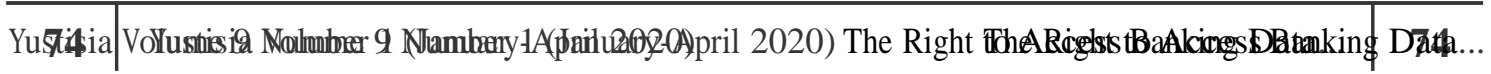




\section{Website:}

Hukumonline. (2018). Gugat Cerai dan Harta Gono Gini, Simak Pandangan Ahli Hukum Keluarga. Retrieved from Hukumonline website: https://www.hukumonline. com/berita/baca/lt5ab61dc00a428/gugat-cerai-dan-harta-gono-gini--simakpandangan-ahli-hukum-keluarga/ 